\title{
Selective-versus-Standard Poststent Dilation for Carotid Artery Disease: A Systematic Review and Meta-Analysis
}

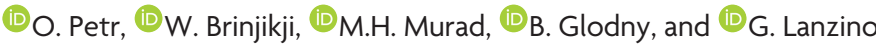

\begin{abstract}
BACKROUND: The safety and efficacy of standard poststent angioplasty in patients undergoing carotid artery stent placement have not been well-established.

PURPOSE: We conducted a systematic review of the literature to evaluate the safety and efficacy of carotid artery stent placement and analyzed outcomes of standard-versus-selective poststent angioplasty.
\end{abstract}

DATA SOURCES: A systematic search of MEDLINE, EMBASE, Scopus, and the Web of Science was performed for studies published between January 2000 and January 2015.

STUDY SELECTION: We included studies with $>30$ patients describing standard or selective poststent angioplasty during carotid artery stent placement.

DATA ANALYSIS: A random-effects meta-analysis was used to pool the following outcomes: periprocedural stroke/TIA, procedurerelated neurologic/cardiovascular morbidity/mortality, bradycardia/hypotension, long-term stroke at last follow-up, long-term primary patency, and technical success.

DATA SYNTHESIS: We included 87 studies with 19,684 patients with 20,378 carotid artery stenoses. There was no difference in clinical $(P=$ .49) or angiographic outcomes $(P=.93)$ in carotid artery stent placement treatment with selective or standard poststent balloon angioplasty. Both selective and standard poststent angioplasty groups had a very high technical success of $>98 \%$ and a low procedurerelated mortality of $0.9 \%$. There were no significant differences between both groups in the incidence of restenosis $(P=.93)$ or procedurerelated complications $(P=.37)$.

LIMITATIONS: No comparison to a patient group without poststent dilation could be performed.

CONCLUSIONS: Our meta-analysis demonstrated no significant difference in angiographic and clinical outcomes among series that performed standard poststent angioplasty and those that performed poststent angioplasty in only select patients.

ABBREVIATION: CAS $=$ carotid artery stent placement

E ndovascular therapy of carotid artery disease has advanced during the past decade and is now considered a valuable treatment alternative to surgery in appropriately selected patients. ${ }^{1-5}$ The indications for carotid endarterectomy were initially estab-

Received August 29, 2016; accepted after revision December 12.

From the Departments of Neurologic Surgery (O.P., G.L.) and Radiology (W.B., G.L.) and Division of Preventive Medicine (M.H.M.), Mayo Clinic, Rochester, Minnesota; and Departments of Radiology (B.G.) and Neurosurgery (O.P.), Medical University Innsbruck, Innsbruck, Austria.

Please address correspondence to Ondra Petr, MD, Mayo Clinic, 200 1st St SW, Rochester, MN 55905; e-mail: petr.ondra@mayo.edu; ondra.petr@yahoo.com

三 Indicates article with supplemental on-line tables.

http://dx.doi.org/10.3174/ajnr.A5103 lished in the North American Symptomatic Carotid Endarterectomy Trial $^{6}$ in 1991, which expanded treatment indications to patients with symptomatic severe or moderate carotid stenoses. Formerly, patients who were not eligible for surgery were treated with percutaneous transluminal balloon angioplasty, ${ }^{7,8}$ first described by Kerber et al in 1980. ${ }^{9}$ Although procedure-related complication rates were similar/comparable for both treatment modalities, ${ }^{7,8,10}$ some potential drawbacks and specific problems occurred due to the endovascular approach, including luminal compromise from catheters and guidewires crossing the stenotic lesions and/or during balloon inflation (temporary carotid occlusion by a balloon and/or wire catheter), intraprocedural thromboembolic events, elastic vessel recoil, or intimal dissection. ${ }^{11}$ Af- 
ter the carotid artery stent placement technique was developed, stent-assisted balloon angioplasty showed better results in eventfree survival and even lower repeat angioplasty rates. ${ }^{11}$ The primarily used balloon-expandable stents were increasingly replaced by self-expanding stents, ${ }^{11,12}$ exhibiting an intrinsic radial expansion force with memory on the stenotic vessel wall. Poststent balloon angioplasty may then be performed to closely appose the stent and intima and, moreover, to expand regions of residual stent narrowing. ${ }^{11}$

Supporters of standard poststent balloon angioplasty (per protocol) indicated that poststent ballooning decreased the incidence of restenosis by re-establishing the normal luminal diameter. However, numerous studies ${ }^{13-15}$ have suggested that poststent balloon dilation increases the likelihood of postprocedural emboli. Moreover, poststent ballooning can increase the probability of reflex bradycardia and hypotension, which might be associated with higher rates of periprocedural and postprocedural complications. ${ }^{16-19}$

Some authors claim that poststent dilation should be performed on a selective, case-by-case basis to maximize patient benefits and limit complications. However, to the best of our knowledge, there is no evidence in the recently published literature supporting the superiority of either of these techniques. Standard poststent balloon angioplasty has become the standard of care in many vascular centers, ${ }^{20-35}$ and only some interventionalists ${ }^{19,36-41}$ prefer performing poststent angioplasty on a selective base. On the basis of the latter studies, standard poststent balloon angioplasty may be associated with additional risks in patients with acceptable angiographic results, without additional post-carotid artery stent placement (CAS) angioplasty.

To evaluate the safety and efficacy of standard poststent angioplasty versus selective poststent angioplasty, we conducted a systematic review and meta-analysis and analyzed outcomes by a series that performed standard poststent balloon angioplasty per protocol on all patients versus those that performed selective poststent balloon angioplasty on only a subset of patients.

\section{MATERIALS AND METHODS \\ Study Selection}

A comprehensive review of the literature was performed by using the keywords "carotid stenosis," "carotid artery disease," "revascularization," "carotid," "stent," "angioplasty," and "endarterectomy" in both "AND" and "OR" combinations to search PubMed, Ovid MEDLINE, Ovid EMBASE, Scopus, and the Web of Science. Inclusion criteria were the following: English language; $>30$ patients; studies published between January 2000 and January 2015; studies that performed poststent angioplasty regardless of patient selection for this procedure; and studies with adequate data on periprocedural and postprocedural complications, outcome and technical success, and primary patency. The exclusion criteria were the following: case reports; in vitro, cadaveric or animal studies; studies with no poststent angioplasty; review articles, guidelines, and technical notes. In case of any inconsistencies or differences with regard to study inclusion/exclusion into the meta-analysis, the senior author decided on inclusion or exclusion (G.L.).
The electronic search was supplemented by contacting experts in the field and reviewing the bibliographies of included studies for relevant publications. Abstracts, methods, results, figures, and tables of full text for detailed review were searched by 2 independent reviewers (neurosurgeon O.P. and radiologist W.B.) for data on poststent balloon angioplasty selection, technical success, long-term primary patency, procedure-related morbidity and mortality, and possible selection-related complications such as periprocedural hypotension and bradycardia. The reference lists of retrieved articles were also screened for additional studies. Furthermore, in case of multiple publications from the same institution and/or the same authors, only the most recent and updated study was considered to avoid inclusion of overlapping patients.

\section{Definition of Treatment Groups}

The objective of this study was to determine whether there was any difference in angiographic and clinical outcomes among series in which standard poststent angioplasty was performed and those in which poststent angioplasty was performed in only select cases. Studies were categorized as either a "standard poststent balloon angioplasty" series or a "selective poststent balloon angioplasty" series. Standard poststent balloon angioplasty series were defined as those in which poststent angioplasty was reportedly performed in all patients, whereas selective poststent balloon angioplasty series were defined as those in which poststent balloon angioplasty was performed in select cases (ie, residual stenosis, poor wall apposition, and so forth).

\section{Data Abstraction}

For each study, we extracted the following descriptive clinical and anatomic information: patient demographics, initial clinical status, and the type of patient selection for the poststent balloon angioplasty (standard versus selective). We studied the following outcomes: periprocedural stroke rates with differentiation of minor and major stroke, periprocedural TIA, procedure-related neurologic or cardiovascular morbidity and mortality, periprocedural myocardial infarction, bradycardia and hypotension rates in all patients distinguishing between hemodynamic changes requiring intervention, long-term stroke rate at last follow-up, long-term primary patency, and technical success. Periprocedural complications were defined as those occurring within 30 days of the carotid artery stent placement.

\section{Statistical Analysis}

We estimated from each study the cumulative incidence (event rate) and 95\% confidence interval for each outcome. Event rates for each intervention were pooled in the meta-analysis across studies by using the random-effects model. ${ }^{42}$ Consequently, there was no need for establishing a hierarchy of analyzed outcomes. Subgroup interactions were conducted by using an interaction test as described by Altman and Bland. ${ }^{43}$ For all outcomes, we quantified between-study heterogeneity by calculating the $\mathrm{I}^{2}$ statistics. ${ }^{44,45}$ Anticipating heterogeneity between studies, we chose this model a priori because it incorporates within-study variance and between-study variance. We were unable to test for publication bias due to the noncomparative nature of these studies. 


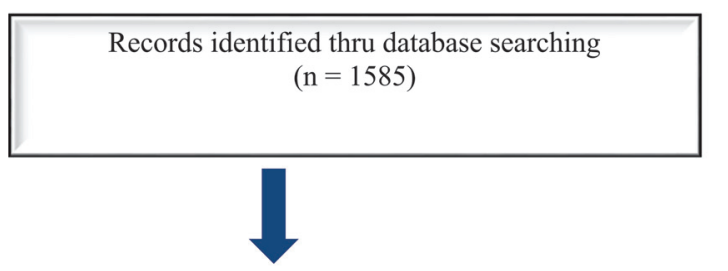

Potentially relevant citations after duplicates (18) removed $(\mathrm{n}=1567)$

Records excluded on basis of titles and abstracts $(\mathrm{n}=1099)$

Full-text articles retrieved for more detailed evaluation

$(n=468)$

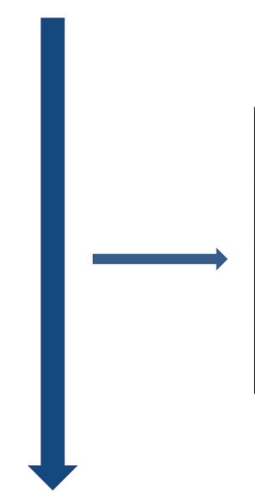

Articles excluded:

- Case reports or too small study populations $(\mathrm{n}=98)$

- Insufficient details on post-stent dilatation and/or postoperative outcome $(n=283)$

$(\mathrm{n}=381)$

Studies included in meta-analysis

$$
(\mathbf{n}=87)
$$

FIG 1. A flow diagram describing our comprehensive literature search. series reporting selective poststent angioplasty included 3395 procedures (16.7\%). Sixty included studies had $\geq 100$ patients. Eleven studies were prospective, and 76 were retrospective. Data are summarized in On-line Table 1. Methodologic characteristics of included studies are listed in On-line Table 2. A flow diagram describing our literature search process is provided in Fig 1.

\section{Complication Rates by Type of Poststent Angioplasty}

There were no statistically significant differences in any of the periprocedural and long-term complication rates by type of poststent angioplasty. Studies reporting selective poststent balloon angioplasty had similar rates of periprocedural stroke $(2.3 \%$; 95\% CI, $1.8 \%-$ $3.0 \%)$ compared with those reporting standard poststent balloon angioplasty (2.6\%; 95\% CI, 2.2\%-3.1\%) ( $P=.36)$. The same was true for long-term stroke rates $(1.3 \%$ versus $1.6 \%, P=.49)$. Major stroke rates were similar in the selective poststent angioplasty group compared with the standard poststent angioplasty group ( $1.2 \%$ versus $1.0 \%, P=.44)$. There was no difference in minor stroke rates in the selective poststent angioplasty group $(1.3 \%$ versus $1.7 \%, P=$ .19). There was no difference in periprocedural TIA rates either $(1.7 \%$ versus $2.2 \%, P=.43)$. The periprocedural myocardial infarction rate was $0.6 \%$ (95\% CI, 0.4\%-1.1\%) in the selective poststent angioplasty group versus $0.7 \%$ (95\% CI, $0.5 \%-1.1 \%$ ) in the standard poststent angioplasty group $(P=.66)$. These data are summarized in On-line Table 3.

\section{RESULTS}

\section{Literature Review}

An initial comprehensive literature search yielded 1585 articles. Eighteen studies were removed as duplicates. On the initial abstract and title review, 1099 were excluded because they were deemed not relevant to the current study. Four hundred sixtyeight studies were reviewed in additional detail; 283 studies were irrelevant because they lacked information about the use of poststent balloon angioplasty and/or postprocedural outcome/complications of patients. Ninety-eight additional studies were excluded because they were either case reports or had too few patients. In total, 87 studies with 19,684 patients with $20,378 \mathrm{ca}$ rotid artery stenoses were included. Series reporting standard poststent angioplasty included 16,983 procedures $(83.3 \%)$, and

\section{Periprocedural Hemodynamic Changes by Type of Poststent Angioplasty}

Studies reporting selective poststent balloon angioplasty had significantly higher rates of bradycardia/hypotension (25.3\%; $95 \%$ CI, $16.9 \%-36.3 \%)$ compared with those undergoing standard poststent angioplasty $(13.3 \%$; 95\% CI, 8.0\%-21.4\%) $(P=.04)$. The same was true for bradycardia/hypotension rates requiring interventions $(18.7 \%$ versus $8.6 \%, P=.01)$. Data are summarized in On-line Table 3.

\section{Angiographic Long-Term Results by Type of Poststent Angioplasty}

There were no statistically significant differences in any of the long-term primary patency rates or technical success by type of 
poststent angioplasty. Studies reporting selective poststent angioplasty had similar long-term primary patency rates (94.3\%; 95\% CI, 90.7\%-96.6\%) compared with those undergoing standard poststent angioplasty $(94.5 \%$; 95\% CI, 92.5\%-95.9\%) ( $P=.93)$. Technical success was $98.7 \%$ (95\% CI, 97.1\%-99.5\%) in the selective poststent angioplasty group versus $99.0 \%$ (95\% CI, 98.6\%-99.3\%) in the standard poststent angioplasty group $(P=$ $.61)$. These data are summarized in On-line Table 3.

\section{Study Heterogeneity and Characteristics}

Significant heterogeneity $\left(\mathrm{I}^{2}\right.$ value $>50 \%$ and $P$ value for the Cochrane Q test $<.05$ ) was noted in the analyses of 2 outcomes: bradycardia/hypotension and bradycardia/hypotension requiring intervention. Therefore, confidence in a pooled summary estimate for these 2 outcomes is limited. $\mathrm{I}^{2}$ values are summarized in On-line Table 3. Methodologic characteristics of included studies are listed in On-line Table 2.

\section{DISCUSSION}

This systematic review and meta-analysis of 87 studies with 19,684 patients reporting either selective and standard poststent balloon angioplasty following carotid artery stent placement demonstrated no difference in clinical or angiographic outcomes in the CAS treatment with selective or standard poststent balloon angioplasty. In our study, we also found that both selective and standard poststent angioplasty groups had very high technical success rates of $>98 \%$ and very low procedurerelated mortality rates of $0.9 \%$. Furthermore, there were no statistically significant differences between both groups in the incidence of restenosis or in procedure-related complication rates. Last, despite the selective poststent balloon angioplasty being associated with higher rates of periprocedural bradycardia/hypotension events, there was a very slight trend toward lower rates of periprocedural TIAs in these patients. These findings are important because they suggest that standard poststent angioplasty is not required during carotid stent placement. The similar rates of primary patency between groups suggest that the addition of standard poststent angioplasty does not provide any definite benefit.

Comparisons of clinical and angiographic outcomes between standard and selective poststent dilations in the literature are limited largely due to the small sizes of most case series. Numerous transcranial Doppler studies ${ }^{14,15,46}$ demonstrate the presence of emboli with each passage across a stenosis with a guidewire, embolic protection device, balloon, or stent, with the highest potential for embolization occurring during poststent dilation when the balloon pushes the stent struts against the atheromatous plaque. Ackerstaff et $\mathrm{al}^{47}$ reported in a series of 550 patients that multiple microemboli ( $>5$ showers) at poststent angioplasty were independently associated with neurologic deficits. While our study found no statistically significant differences between the selective and the standard poststent angioplasty groups in terms of risk of stroke and TIA, the standard poststent angioplasty producing no benefit in primary patency suggests that this additional procedure may not always be necessary.

There has been considerable debate in the literature with regard to hemodynamic depression as a possible predictor of ad- verse events. Some studies ${ }^{16,17,19,48}$ suggested that hypotension may result in a greater incidence of periprocedural complications, and even death. To our knowledge, in the largest study to date of 103 patients evaluating the effect of poststent ballooning on hemodynamic stability during and after carotid stent placement, Qazi et a ${ }^{19}$ demonstrated that poststent balloon angioplasty was a significant predictor of hemodynamic depression (OR, 3.8; 95\% CI, $1.3-11 ; P<.01$ ) with increased risk of major adverse cardiovascular events. Gupta et al ${ }^{16}$ showed that patients with persistent hypotension are at a higher risk of developing an adverse clinical event such as stroke or death after CAS. On the other hand, our study found higher rates of bradycardia/hypotension in patients treated with selective poststent angioplasty compared with standard poststent angioplasty; however, there was no impact on procedure-related complications. The reasons behind this surprising finding in our study are not known. Presumably, patients who undergo selective post-CAS dilation are more likely to have rigid stenoses or insufficient alignment of the stent with the vessel wall compared with those undergoing standard post-CAS angioplasty. Consequently, selective post-CAS dilation is then performed in these cases. During this procedure, relevant hemodynamic events such as bradycardia and/or hypotension can occur, reflecting forced opening of the rigid stenosis.

\section{Limitations}

We acknowledge that our meta-analysis has several limitations. Studies reporting only carotid artery stent placement without subsequent angioplasty were excluded. With this design, no comparison with a group without poststent dilation could be performed. There was a paucity of studies comparing outcomes of patients who received no poststent angioplasty and those who did. Our results should not be interpreted as saying that poststent angioplasty is ineffective because it is likely useful on a case-bycase basis. Rather, our results should be interpreted to say that there is no difference in angiographic and clinical outcomes among patients undergoing standard poststent angioplasty and those undergoing selective poststent angioplasty.

Ecologic bias (eg, comparisons are made across studies and not within studies), the possibility of publication bias, and statistical heterogeneity are important limitations that affect inferences derived from this study. None of the included studies were randomized or included control groups. There was no detailed information regarding the indications for selective poststent angioplasty. Similarly, there was no information about residual stent narrowing before performing balloon angioplasty. However, given the contemporary and widely accepted literature evidence for treatment of carotid artery disease, all included studies most likely had similar strict indications for carotid artery stent placement.

\section{CONCLUSIONS}

This meta-analysis of $>87$ series reporting selective and standard poststent balloon angioplasty following carotid artery stent placement demonstrated that both standard and selective approaches were associated with low rates of procedure-related neurologic or cardiovascular morbidity and high rates of longterm primary patency of $>94 \%$. There were no statistically 
significant differences in clinical or angiographic outcomes between series reporting standard and selective poststent angioplasty. Comparative prospective studies are needed to confirm our findings.

Disclosures: Giuseppe Lanzino-UNRELATED: Consultancy: Covidien/Medtronic.* *Money paid to the institution.

\section{REFERENCES}

1. Ricotta JJ 2nd, Piazza M. Carotid endarterectomy or carotid artery stenting? Matching the patient to the intervention. Perspect Vasc Surg Endovasc Ther 2010;22:124-36 CrossRef Medline

2. Ederle J, Bonati LH, Dobson J, et al; CAVATAS Investigators. Endovascular treatment with angioplasty or stenting versus endarterectomy in patients with carotid artery stenosis in the Carotid and Vertebral Artery Transluminal Angioplasty Study (CAVATAS): long-term follow-up of a randomised trial. Lancet Neurol 2009;8: 898-907 CrossRef Medline

3. Ederle J, Dobson J, Featherstone RL, et al; International Carotid Stenting Study investigators. Carotid artery stenting compared with endarterectomy in patients with symptomatic carotid stenosis (International Carotid Stenting Study): an interim analysis of a randomised controlled trial. Lancet 2010;375:985-97 CrossRef Medline

4. Yadav JS, Wholey MH, Kuntz RE, et al; Stenting and Angioplasty with Protection in Patients at High Risk for Endarterectomy Investigators. Protected carotid-artery stenting versus endarterectomy in high-risk patients. $N$ Engl J Med 2004;351:1493-501 CrossRef Medline

5. Brott TG, Hobson RW 2nd, Howard G, et al; CREST Investigators. Stenting versus endarterectomy for treatment of carotid-artery stenosis. N Engl J Med 2010;363:11-23 CrossRef Medline

6. North American Symptomatic Carotid Endarterectomy Trial Collaborators. Beneficial effect of carotid endarterectomy in symptomatic patients with high-grade carotid stenosis. $N$ Engl J Med 1991;325:445-53 CrossRef Medline

7. Kachel R. Results of balloon angioplasty in the carotid arteries. $J$ Endovasc Surg 1996;3:22-30 Medline

8. Gil-Peralta A, Mayol A, Marcos JR, et al. Percutaneous transluminal angioplasty of the symptomatic atherosclerotic carotid arteries: results, complications, and follow-up. Stroke 1996;27:2271-73 CrossRef Medline

9. Kerber CW, Cromwell LD, Loehden OL. Catheter dilatation of proximal carotid stenosis during distal bifurcation endarterectomy. AJNR Am J Neuroradiol 1980;1:348-49 Medline

10. Ferguson GG, Eliasziw M, Barr HW, et al. The North American Symptomatic Carotid Endarterectomy Trial: surgical results in 1415 patients. Stroke 1999;30:1751-58 CrossRef Medline

11. Phatouros CC, Higashida RT, Malek AM, et al. Carotid artery stent placement for atherosclerotic disease: rationale, technique, and current status. Radiology 2000;217:26-41 CrossRef Medline

12. Mathur A, Dorros G, Iyer SS, et al. Palmaz stent compression in patients following carotid artery stenting. Cathet Cardiovasc Diag 1997;41:137-40 Medline

13. Martin JB, Pache JC, Treggiari-Venzi M, et al. Role of the distal balloon protection technique in the prevention of cerebral embolic events during carotid stent placement. Stroke 2001;32: 479-84 Medline

14. Manninen HI, Räsänen HT, Vanninen RL, et al. Stent placement versus percutaneous transluminal angioplasty of human carotid arteries in cadavers in situ: distal embolization and findings at intravascular US, MR imaging and histopathologic analysis. Radiology 1999;212:483-92 CrossRef Medline

15. Vos JA, van den Berg JC, Ernst SM, et al. Carotid angioplasty and stent placement: comparison of transcranial Doppler US data and clinical outcome with and without filtering cerebral protection devices in 509 patients. Radiology 2005;234:493-99 CrossRef Medline

16. Gupta R, Abou-Chebl A, Bajzer CT, et al. Rate, predictors, and consequences of hemodynamic depression after carotid artery stenting. J Am Coll Cardiol 2006;47:1538-43 CrossRef Medline

17. Howell M, Krajcer Z, Dougherty K, et al. Correlation of periprocedural systolic blood pressure changes with neurological events in high-risk carotid stent patients. J Endovasc Ther 2002;9:810-16 CrossRef Medline

18. Park BD, Divinagracia T, Madej O, et al. Predictors of clinically significant postprocedural hypotension after carotid endarterectomy and carotid angioplasty with stenting. J Vasc Surg 2009;50: 526-33 CrossRef Medline

19. Qazi U, Obeid TE, Enwerem N, et al. The effect of ballooning following carotid stent deployment on hemodynamic stability. J Vasc Surg 2014;59:756-60 CrossRef Medline

20. Ghandehari K, Edraki K, Karimi M, et al. Complications of angioplasty and stenting of cervicocerebral arteries in Iran. Asian Cardiovasc Thorac Ann 2010;18:49-53 CrossRef Medline

21. Ielasi A, Latib A, Godino C, et al. Clinical outcomes following protected carotid artery stenting in symptomatic and asymptomatic patients. J Endovasc Ther 2010;17:298-307 CrossRef Medline

22. Micari A, Stabile E, Cremonesi A, et al. Carotid artery stenting in octogenarians using a proximal endovascular occlusion cerebral protection device: a multicenter registry. Catheter Cardiovasc Interv 2010;76:9-15 CrossRef Medline

23. Montorsi P, Galli S, Ravagnani P, et al. Randomized trial of predilation versus direct stenting for treatment of carotid artery stenosis. Int J Cardiol 2010;138:233-38 CrossRef Medline

24. Stabile E, Salemme L, Sorropago G, et al. Proximal endovascular occlusion for carotid artery stenting: results from a prospective registry of 1,300 patients. J Am Coll Cardiol 2010;55:1661-67 CrossRef Medline

25. Almekhlafi MA, Couillard PL, Pandya A, et al. Outcomes after carotid angioplasty and stenting in symptomatic octogenarians. Can J Neurol Sci 2011;38:446-51 CrossRef Medline

26. Satya K, Dougherty K, Lee VV, et al. Determinants and outcomes of asystole during carotid artery stenting. J Endovasc Ther 2011;18: 513-17 CrossRef Medline

27. Kimiagar I, Gur AY, Auriel E, et al. Long-term follow-up of patients after carotid stenting with or without distal protective device in a single tertiary medical center. Vasc Endovasc Surg 2012;46:536-41 CrossRef Medline

28. Mazzaccaro D, Occhiuto MT, Stegher S, et al. Long-term results of carotid artery stenting in patients $\mathbf{8 0}$ years and older. Perspect Vasc Surg Endovasc Ther 2012;24:49-54 CrossRef Medline

29. Mohammadian R, Sohrabi B, Mansourizadeh R, et al. Unprotected carotid artery stenting: complications in $\mathbf{6}$ months follow-up. Neuroradiology 2012;54:225-30 CrossRef Medline

30. Dumont TM, Wach MM, Mokin M, et al. Perioperative complications after carotid artery stenting: a contemporary experience from the University at Buffalo neuroendovascular surgery team. Neurosurgery 2013;73:689-93; discussion 693-94 CrossRef Medline

31. Lago A, Parkhutik V, Tembl JI, et al. Diabetes does not affect outcome of symptomatic carotid stenosis treated with endovascular techniques. Eur Neurol 2013;69:263-69 CrossRef Medline

32. Ullery BW, Orlova K, Shang EK, et al. Results of carotid angioplasty and stenting are equivalent for critical versus high-grade lesions in patients deemed high risk for carotid endarterectomy. J Surg Res 2013;185:21-26 CrossRef Medline

33. Biggs NG, Rangarajan S, McClure DN. Has carotid artery stenting found its place? A 10-year regional centre perspective. ANZ J Surg 2016;86:179-83 CrossRef Medline

34. Hernández-Fernández F, Parrilla G, Garcia-Villalba B, et al. Comparison between proximal versus distal protection devices in 287 cases of carotid revascularization using angioplasty and stenting: periprocedure complications, morbidity, and mortality. Cardiovasc Intervent Radiol 2014;37:639-45 CrossRef: Medline 
35. Morgan CE, Lee CJ, Chin JA, et al. High-risk anatomic variables and plaque characteristics in carotid artery stenting. Vasc Endovascular Surg 2014;48:452-59 CrossRef Medline

36. Cohen JE, Gomori JM, Itshayek E, et al. Ischemic complications after tailored carotid artery stenting in different subpopulations with high-grade stenosis: feared but rare. J Clin Neurosci 2015;22: 189-94 CrossRef Medline

37. Ogata $\mathrm{A}$, Sonobe $\mathrm{M}$, Kato $\mathrm{N}$, et al. Carotid artery stenting without post-stenting balloon dilatation. J Neurointerv Surg 2014;6:517-20 CrossRef Medline

38. Oteros Fernandez R, Jimenez-Gomez E, Bravo-Rodriguez F, et al. Unprotected carotid artery stenting in symptomatic patients with high-grade stenosis: results and long-term follow-up in a singlecenter experience. AJNR Am J Neuroradiol 2012;33:1285-91 CrossRef Medline

39. Tallarita T, Rabinstein AA, Cloft H, et al. Are distal protection devices 'protective' during carotid angioplasty and stenting? Stroke 2011;42:1962-66 CrossRef Medline

40. Mansour OY, Weber J, Niesen W, et al. Carotid angioplasty and stenting without protection devices: safety and efficacy concernssingle center experience. Clin Neuroradiol 2011;21:65-73 CrossRef Medline

41. González A, Gil-Peralta A, Mayol A, et al. Internal carotid artery stenting in patients with near occlusion: 30-day and long-term outcome. AJNR Am J Neuroradiol 2011;32:252-58 CrossRef Medline

42. DerSimonian R, Laird N. Meta-analysis in clinical trials. Control Clin Trials 1986;7:177-88 CrossRef Medline

43. Altman DG, Bland JM. Interaction revisited: the difference between two estimates. BMJ 2003;326:219 CrossRef Medline

44. Higgins JP, Thompson SG, Deeks JJ, et al. Measuring inconsistency in meta-analyses. BMJ 2003;327:557-60 CrossRef Medline

45. Higgins JP, Thompson SG. Quantifying heterogeneity in a metaanalysis. Stat Med 2002;21:1539-58 CrossRef Medline

46. Rubartelli P, Brusa G, Arrigo A, et al. Transcranial Doppler monitoring during stenting of the carotid bifurcation: evaluation of two different distal protection devices in preventing embolization. J Endovasc Ther 2006; 13:436-42 CrossRef Medline

47. Ackerstaff RG, Suttorp MJ, van den Berg JC, et al; Antonius Carotid Endarterectomy, Angioplasty, and Stenting Study Group. Prediction of early cerebral outcome by transcranial Doppler monitoring in carotid bifurcation angioplasty and stenting. J Vasc Surg 2005;41:618-24 CrossRef Medline

48. Park B, Shapiro D, Dahn M, et al. Carotid artery angioplasty with stenting and postprocedure hypotension. Am J Surg 2005;190: 691-95 CrossRef Medline

49. Morrish W, Grahovac S, Douen A, et al. Intracranial hemorrhage after stenting and angioplasty of extracranial carotid stenosis. AJNR Am J Neuroradiol 2000;21:1911-16 Medline

50. Ahmadi R, Schillinger M, Lang W, et al. Carotid artery stenting in older patients: is age a risk factor for poor outcome? J Endovasc Ther 2002;9:559-65 CrossRef Medline

51. Criado FJ, Lingelbach JM, Ledesma DF, et al. Carotid artery stenting in a vascular surgery practice. J Vasc Surg 2002;35:430-34 CrossRef Medline

52. Hobson RW 2nd, Lal BK, Chakhtoura EY, et al. Carotid artery closure for endarterectomy does not influence results of angioplastystenting for restenosis. J Vasc Surg 2002;35:435-38 CrossRef Medline

53. Kao HL, Lin LY, Lu CJ, et al. Long-term results of elective stenting for severe carotid artery stenosis in Taiwan. Cardiology 2002;97: 89-93 CrossRef Medline

54. Antonius Carotid Endaterectomy, Angioplasty, and Stenting Study Group. Transcranial Doppler monitoring in angioplasty and stenting of the carotid bifurcation. J Endovasc Ther 2003;10:702-10 CrossRef Medline

55. Cernetti C, Reimers B, Picciolo A, et al. Carotid artery stenting with cerebral protection in 100 consecutive patients: immediate and two-year follow-up results. Ital Heart J 2003;4:695-700 Medline

56. Cremonesi A, Manetti R, Setacci F, et al. Protected carotid stenting: clinical advantages and complications of embolic protection devices in 442 consecutive patients. Stroke 2003;34:1936-41 CrossRef Medline

57. Tsuura M, Terada T, Matsumoto $\mathrm{H}$, et al. Clinical results of stenting for cervical internal carotid stenoses. Interv Neuroradiol 2003; 9:133-36 Medline

58. Wholey MH, Wholey MH, Tan WA, et al. A comparison of balloonmounted and self-expanding stents in the carotid arteries: immediate and long-term results of more than $\mathbf{5 0 0}$ patients. J Endovasc Ther 2003;10:171-81 CrossRef Medline

59. Eskandari MK, Longo GM, Vijungco JD, et al. Does carotid stenting measure up to endarterectomy? A vascular surgeon's experience. Arch Surg 2004;139:734-38 CrossRef Medline

60. Faries PL, Dayal R, Clair DG, et al. Continuity in the treatment of carotid artery disease: results of a carotid stenting program initiated by vascular surgeons. Ann Vasc Surg 2004;18:669-76 CrossRef Medline

61. Kastrup A, Schulz JB, Raygrotzki S, et al. Comparison of angioplasty and stenting with cerebral protection versus endarterectomy for treatment of internal carotid artery stenosis in elderly patients. J Vasc Surg 2004;40:945-51 CrossRef Medline

62. Sadato A, Satow T, Ishii A, et al. Use of a large angioplasty balloon for predilation is a risk factor for embolic complications in protected carotid stenting. Neurol Med Chir (Tokyo) 2004;44:337-42; discussion 343 CrossRef Medline

63. Bonaldi G, Aiazzi L, Baruzzi F, et al. Angioplasty and stenting of the cervical carotid bifurcation under filter protection: a prospective study in a series of 53 patients. J Neuroradiol 2005;32:109-17 CrossRef Medline

64. Cayne NS, Faries PL, Trocciola SM, et al. Carotid angioplasty and stent-induced bradycardia and hypotension: impact of prophylactic atropine administration and prior carotid endarterectomy. J Vasc Surg 2005;41:956-61 CrossRef Medline

65. Coppi G, Moratto R, Silingardi R, et al. PRIAMUS: proximal flow blockage cerebral protection during carotid stenting-results from a multicenter Italian registry. J Cardiovasc Surg (Torino) 2005; 46:219-27 Medline

66. Eskandari MK, Longo GM, Matsumura JS, et al. Carotid stenting done exclusively by vascular surgeons: first 175 cases. Ann Surg 2005;242:431-36; discussion 436-38 Medline

67. Kadkhodayan Y, Derdeyn CP, Cross DT 3rd, et al. Procedure complications of carotid angioplasty and stent placement without cerebral protection devices. Neurosurg Focus 2005; 18:e1 Medline

68. Li SM, Li D, Ling F, et al. Carotid artery stenting: experience of a single institute in China. Interv Neuroradiol 2005;11:205-12 Medline

69. Lin PH, Bush RL, Peden EK, et al. Carotid artery stenting with neuroprotection: assessing the learning curve and treatment outcome. Am J Surg 2005;190:850-57 CrossRef Medline

70. Longo GM, Kibbe MR, Eskandari MK. Carotid artery stenting in octogenarians: is it too risky? Ann Vasc Surg 2005;19:812-16 CrossRef Medline

71. Reimers B, Sievert H, Schuler GC, et al. Proximal endovascular flow blockage for cerebral protection during carotid artery stenting: results from a prospective multicenter registry. J Endovasc Ther 2005;12:156-65 CrossRef Medline

72. Chaer RA, Derubertis BG, Trocciola SM, et al. Safety and efficacy of carotid angioplasty and stenting in high-risk patients. Am Surg 2006;72:694-98; discussion 698-99 Medline

73. Faries PL, Trocciola SM, De Rubertis B, et al. Hemodynamic instability after carotid artery angioplasty and stening is associated with increased age and female gender. Vas Dis Management 2006;3:200-05

74. Gröschel K, Ernemann U, Schulz JB, et al. Statin therapy at carotid angioplasty and stent placement: effect on procedure-related 
stroke, myocardial infarction, and death. Radiology 2006;240: 145-51 CrossRef Medline

75. Halabi M, Gruberg L, Pitchersky S, et al. Carotid artery stenting in surgical high-risk patients. Catheter Cardiovasc Interv 2006;67: 513-18 CrossRef Medline

76. Kwon BJ, Han MH, Kang HS, et al. Protection filter-related events in extracranial carotid artery stenting: a single-center experience. J Endovasc Ther 2006;13:711-22 CrossRef Medline

77. Nano G, Dalainas I, Bianchi P, et al. Ballooning-induced bradycardia during carotid stenting in primary stenosis and restenosis. Neuroradiology 2006;48:533-36 CrossRef Medline

78. Cotroneo AR, Iezzi R. Cutting balloon angioplasty (CBA) versus conventional balloon angioplasty (PTA) in the pre-dilatation of carotid artery stenosis: our preliminary experience. Cardiovasc Intervent Radiol 2007;30:1210-17 CrossRef Medline

79. Criado E, Fontcuberta J, Orgaz A, et al. Transcervical carotid stenting with carotid artery flow reversal: 3-year follow-up of 103 stents. J Vasc Surg 2007;46:864-69 CrossRef Medline

80. Kawarada O, Yokoi Y, Takemoto K, et al. Double-wire technique in balloon-protected carotid artery stenting. J Interv Cardio 2007;20: 55-62 CrossRef Medline

81. Lin PH, Zhou W, Kougias P, et al. Factors associated with hypotension and bradycardia after carotid angioplasty and stenting. $J$ Vasc Surg 2007;46:846-53; discussion 853-54 CrossRef Medline

82. Maynar M, Baldi S, Rostagno R, et al. Carotid stenting without use of balloon angioplasty and distal protection devices: preliminary experience in 100 cases. AJNR Am J Neuroradiol 2007;28:1378-83 CrossRef Medline

83. Van der Heyden J, Suttorp MJ, Bal ET, et al. Staged carotid angioplasty and stenting followed by cardiac surgery in patients with severe asymptomatic carotid artery stenosis: early and long-term results. Circulation 2007;116:2036-42 CrossRef Medline

84. Younis GA, Gupta K, Mortazavi A, et al. Predictors of carotid stent restenosis. Catheter Cardiovasc Interv 2007;69:673-82 CrossRef Medline

85. AbuRahma AF, Bates MC, Eads K, et al. Safety and efficacy of carotid angioplasty/stenting in 100 consecutive high surgical risk patients: immediate and long-term follow-up. Vasc Endovasc Surg 2008;42:433-39 CrossRef Medline

86. Bussière M, Pelz DM, Kalapos $\mathrm{P}$, et al. Results using a self-expanding stent alone in the treatment of severe symptomatic carotid bifurcation stenosis. J Neurosurg 2008;109:454-60 CrossRef Medline

87. Bussière $\mathrm{M}$, Lownie $\mathrm{SP}$, Lee $\mathrm{D}$, et al. Hemodynamic instability during carotid artery stenting: the relative contribution of stent deployment versus balloon dilation. J Neurosurg 2009;110:905-12 CrossRef Medline

88. Buszman P, Debiński M, Gruszka A, et al. Early and late outcomes of percutaneous transluminal angioplasty of cephalad arteries. Kardiol Pol 2008;66:233-42, discussion 243 Medline

89. Castriota F, de Campos Martins EC, Setacci C, et al. Cutting balloon angioplasty in percutaneous carotid interventions. $J$ Endovasc Ther 2008;15:655-62 CrossRef Medline

90. Cieri E, De Rango P, Maccaroni MR, et al. Is haemodynamic depression during carotid stenting a predictor of peri-procedural complications? Eur J Vasc Endovasc Surg 2008;35:399-404 CrossRef Medline

91. Diehm N, Katzen BT, Dick F, et al. Influence of stent type on hemodynamic depression after carotid artery stent placement. J Vasc Interv Radiol 2008;19:23-30 CrossRef Medline

92. Henry M, Henry I, Polydorou A, et al. Carotid angioplasty and stenting in octogenarians: is it safe? Catheter Cardiovasc Interv 2008;72:309-17 CrossRef Medline

93. Pieniazek P, Musialek P, Kablak-Ziembicka A, et al. Carotid artery stenting with patient- and lesion-tailored selection of the neuroprotection system and stent type: early and 5-year results from a prospective academic registry of 535 consecutive procedures (TARGET-CAS). J Endovasc Ther 2008;15:249-62 CrossRef Medline
94. Roffi M, Greutmann M, Schwarz U, et al. Flow impairment during protected carotid artery stenting: impact of filter device design. $J$ Endovasc Ther 2008;15:103-09 CrossRef Medline

95. Velez CA, White CJ, Reilly JP, et al. Carotid artery stent placement is safe in the very elderly ( $>$ or $=\mathbf{8 0}$ years). Catheter Cardiovasc Interv 2008;72:303-08 CrossRef Medline

96. Brown KE, Usman A, Kibbe MR, et al. Carotid stenting using tapered and nontapered stents: associated neurological complications and restenosis rates. Ann Vasc Surg 2009;23:439-45 CrossRef Medline

97. Goldstein LJ, Khan HU, Sambol EB, et al. Carotid artery stenting is safe and associated with comparable outcomes in men and women. J Vasc Surg 2009;49:315-23; discussion 323-24 CrossRef Medline

98. Simonetti G, Gandini R, Versaci F, et al. Carotid artery stenting: findings based on 8 years' experience [in English, Italian]. Radiol Med 2009;114:95-110 CrossRef Medline

99. Theron J, Venturi C, Reul J, et al. Immediate and 30-day clinical outcome of patients treated with the TwinOne cerebral protection system: multicenter experience in 217 cases. Cardiovasc Intervent Radiol 2009;32:1139-45 CrossRef Medline

100. Veselka J, Cerná D, Zimolová $P$, et al. Feasibility, safety, and early outcomes of direct carotid artery stent implantation with use of the FilterWire EZ Embolic Protection System. Catheter Cardiovasc Interv 2009;73:733-38 CrossRef Medline

101. Chung C, Cayne NS, Adelman MA, et al. Improved hemodynamic outcomes with glycopyrrolate over atropine in carotid angioplasty and stenting. Perspect Vasc Surg Endovasc Ther 2010;22:164-70 CrossRef Medline

102. Shabaneh B, Dougherty K, Hernandez E, et al. Catheter aspiration thrombectomy during carotid stenting is safe and potentially efficacious: a pilot retrospective study. J Cardiovasc Surg (Torino) 2010;51:865-72 Medline

103. Knur R. Carotid artery stenting with distal filter protection: single-center experience in high-surgical-risk patients. Heart Vessels 2011;26:125-30 CrossRef Medline

104. Mak CS, Chambers BR, Clark DJ, et al. Multidisciplinary approach to carotid stenting. Intern Med J 2011;41:789-94 CrossRef Medline

105. Mendiz OA, Sampaolesi AH, Londero HF, et al. Initial experience with transradial access for carotid artery stenting. Vasc Endovasc Surg 2011;45:499-503 CrossRef Medline

106. Rizwan Khalid M, Khalid F, Farooqui FA, et al. Can experienced physicians with high peripheral interventional volume but low carotid artery stenting (CAS) volume achieve low complication rates during CAS? EuroIntervention 2011;6:744-47 CrossRef Medline

107. Wu YM, Wong HF, Chen YL, et al. Carotid stenting of asymptomatic and symptomatic carotid artery stenoses with and without the use of a distal embolic protection device. Acta Cardiol 2011;66: 453-58 CrossRef Medline

108. Harada K, Morioka J, Higa T, et al. Significance of combining distal filter protection and a guiding catheter with temporary balloon occlusion for carotid artery stenting: clinical results and evaluation of debris capture. Ann Vasc Surg 2012;26:929-36 CrossRef Medline

109. Moratto R, Veronesi J, Silingardi R, et al. Urgent carotid artery stenting with technical modifications for patients with transient ischemic attacks and minor stroke. J Endovasc Ther 2012;19:627-35 CrossRef Medline

110. Kessler I, Gory B, Macian F, et al. Carotid artery stenting in patients with symptomatic carotid stenosis: a single-center series. J Neuroradiol 2013;40:38-44 CrossRef Medline

111. Miyawaki S, Maeda K. Surgical treatment for cervical carotid artery stenosis in the elderly: importance of perioperative management of ischemic cardiac complications. Neurol Med Chir (Tokyo) 2014;54:120-25 CrossRef Medline

112. Shinozaki N, Ogata N, Ikari Y. Plaque protrusion detected by intravascular ultrasound during carotid artery stenting. J Stroke Cerebrovasc Dis 2014;23:2622-25 CrossRef Medline 